\title{
Community needs assessment of key populations- at-risk of HIV/AIDS in Nigeria's capital territory
}

\author{
Godwin Asuquo ${ }^{*}$, David Owolabi, Ali Onoja, Uche Okoro, Floria Durueke \\ From International Symposium HIV and Emerging Infectious Diseases 2014 \\ Marseille, France. 21-23 May 2013
}

\begin{abstract}
Introduction (aim)
Nigeria currently has one of the highest HIV and AIDS epidemic burden worldwide. Prevalence among key populations is currently, $34.1 \%$ (brothel-based sex workers), 21.95 (non-brothel-based), 37.6\% (MSMs) and 9.3\% for IDUs respectively. A huge gaps exists in the national response to key populations as a result of socio-cultural barriers and unfavorable political and legislative environment. This has become accentuated by the recently enacted anti-gay law. The Federal Capital Administration in collaboration with UNDP and UNFPA in 2013 commissioned a study on key populations in the Capital territory to identify services available to them, the gaps and opportunities for scaling up municipal responses for MSMs, FSWs and IDUs.
\end{abstract}

\section{Materials and methods}

A cross sectional study relying on the needs assessment methodology which included a community social survey, community mapping and focus group discussions. A total of 120 (70 sex workers, 30 MSMs and 20 IDUs) participated in the study. In-depth interviews were conducted for policy makers and technical leads from government agencies, NGOs and development partners. Institutional analysis of relevant NGOs preceded a desk review of the response to key populations in Nigeria and a validation workshop was conducted to validate the findings.

\section{Results}

About 17,117 FSWs were mapped in 1004 hotspots, while, 692 MSMs were located in 692 hot spots and 135 IDUs in 16 hotspots in the FCT. About 689 non-governmental organizations were providing services with the majority (40\%) providing HCT services, $34 \%$, condom programming, $20 \%$ peer education and $16 \%$, youth friendly

Africa Center for Health Care Leadership Development, Abuja, Nigeria services. None of the NGOs was providing STI services while only $10 \%$ provided lubricants. HIV/AIDS risk perception and current knowledge of prevention of sexual transmission was generally low (32\%). Social stigma, poor coordination and inadequate government support were identified as major barriers to scaling up services.

\section{Conclusion}

The findings support the need for the development of a municipal action plan for key populations in the FCT based on the identified priorities and the review of the national HIV/AIDS strategy to be more responsive to the needs of key populations.

Published: 23 May 2014

doi:10.1186/1471-2334-14-S2-P29

Cite this article as: Asuquo et al: Community needs assessment of key populations-at-risk of HIV/AIDS in Nigeria's capital territory. BMC Infectious Diseases 2014 14(Suppl 2):P29.

Submit your next manuscript to BioMed Central and take full advantage of:

- Convenient online submission

- Thorough peer review

- No space constraints or color figure charges

- Immediate publication on acceptance

- Inclusion in PubMed, CAS, Scopus and Google Scholar

- Research which is freely available for redistribution 